\title{
21st Century Skills and Finnish Student Teachers' Perceptions about the Ideal RE Teacher Today and in the Future
}

\author{
Kaisa Viinikka and Martin Ubani \\ University of Eastern Finland \\ Joensuu, Finland \\ Tuuli Lipiäinen and Arto Kallioniemi \\ University of Helsinki \\ Helsinki, Finland
}

\begin{abstract}
This study investigates religious education (hereinafter referred to as "RE") student teachers' perceptions about what constitutes a successful teacher in the next 20-30 years. The study focuses on RE student teachers in teacher education in Finland. The students were studied in the light of a 21st century skills framework. The data were gathered using a questionnaire $(\mathrm{N}=43)$ and interviews $(\mathrm{n}=8)$. The analysis of the interviews was deductive content analysis with a quantification of the results. There were several results from the study. For instance, the RE student teachers' expectations of professional development are connected to their perceptions of the task requirements. The RE student teachers perceived all kinds of interaction skills as an essential part of RE teacher competence in the future along with dialogue skills. The RE student teachers also emphasised learning to learn and critical thinking skills as the core skills of a successful RE teacher in the future. The participants seemed to highlight all the different literacy skills (information, media, technology and religious) as the core skills of a successful RE teacher. Especially religious literacy was considered to be a key skill in the competence of the RE teacher in the future.
\end{abstract}

Keywords: teacher education; religious education; 21st century skills; student teachers.

\section{Introduction}

The aim of this article is to examine religious education (hence RE) student teachers' perceptions about a successful teacher in the next 20-30 years. In the literature, challenges and changes in Western societies concerning religions, migration and radicalisation have been widely acknowledged (e.g. Jackson, 
2014). There are many developments that have been connected with these changes, including secularization, pluralisation, multiculturalism and the modernisation and individualisation of religions (Jackson, 2014; Markkola, 2003). Digitalisation has created "new literacies", such as digital literacy and information literacy, which cannot be bypassed in the 21st century (Lankshear \& Knobel, 2011). Among other things, the transitions in societies from an industrial-based to information-based outlook have also caused public education to face new questions. It has been argued that, nowadays, education has to be able to meet the needs of more abstract working conditions, emphasising "new" transferable skills, such as information and technological skills, the ability to learn, collaborate and solve problems, empathy skills, social activity and entrepreneurial skills, instead of subject specific content knowledge to foster citizenship for the future (Griffin, Care, \& McGaw, 2012; Binkley et al., 2012). In addition, learning has increasingly been taking place in informal learning environments that are dialogical and blended (UNESCO, 2012; Kumpulainen \& Mikkola, 2015; Bonk \& Graham, 2004; Singh, 2015.). In line with these developments, phenomenon-based learning and skill-acquisition was also emphasised in Finland in the recent national core curriculum regarding content learning (NCCBE, 2014; Lonka, 2018).

In addition to the curricular demands for public education, the question of educating for 21st century skills is integrally a question of teacher education. Several evaluations have highlighted the quality of Finnish schooling and its teachers (Sahlberg \& Korpela, 2015). In Finland, teacher education aims at the balanced development of the teacher's personal and professional competences: the student teachers are to develop their own personal pedagogical theory in their studies (Lavonen \& Laaksonen, 2009). For decades, there has existed a strong international research tradition in the literature stressing the importance of the reflection of teacher (i.e. Schön, 1983; Shulman, 1986, 1987). Finnish teacher education also aims to educate teachers who are capable of researchbased pedagogical thinking (Niemi, Kallioniemi, \& Toom, 2016). Educating teachers for RE in Finland is a part of subject teacher education at the universities. The subject teachers are required to complete a master's level degree in Theology or Religious Studies. The RE teachers often have psychology or history and social sciences as a second teaching subject. There are two Finnish speaking theological faculties and departments in Finland. The University of Eastern Finland and University of Helsinki have a specific teacher education programme for RE teachers, although the majority of the pedagogical studies (60 credits) are integrated with other subject student teacher groups and are organised in the Faculties of Educational Sciences. There, the admittance rate of students to the programme is significantly low: the teaching profession is popular in Finland (Kallioniemi \& Ubani, 2016).

We perceive the education of teachers of RE integral in the task of equipping students with comprehensive skills for navigating in the secularised and pluralised realities the citizens of today and tomorrow (Poulter, Rissanen, \& Ubani, 2019). As Biseth (2009) describes, in Nordic countries, RE in public education has increasingly been appointed with tasks related to 
multiculturalism, worldviews and plurality (Ubani, 2018; Ubani, Rissanen, \& Poulter, 2019). Similar to most European countries, RE is a compulsory subject in Finnish public schools. Usually there is one RE lesson each week in all school years at the comprehensive level. It is given according to the pupil's own religion: there are objectives for several different religions and for secular ethics (an alternative subject mainly for pupils who do not belong to any religious communities). In Finland, RE is not a confessional subject, although the content somewhat emphasises the pupil's own religion tradition (Kallioniemi \& Ubani, 2016; NCCBE, 2014). The aim of RE is to produce all-round literacy. According to the general aims of RE, the task of this education was to make the pupils familiar with their own religions, with the Finnish religious traditions and with other religions to help the pupils understand the cultural and human meaning of religion, to introduce the pupils to ethical responsibility and to help them understand the ethical dimension of religion (NCCBE, 2014). In order to study the student teachers' perceptions about the demands of their profession with regards to the demands of transforming curricular and societal demands we have formulated the research question as follows:

What do the RE student teachers perceive as the core skills of an ideal RE teacher in the next 20-30 years?

\section{1st century skills as well as RE and developing teacher's professionalism}

In the literature, the emergent emphases on life skills, workforce skills, interpersonal skills, applied skills and non-cognitive skills have stressed the need to conceptualise and educate pupils generic transferable skill set required in knowledge based societies in the future (Silva, 2008; Geisinger, 2016). One such more novel learning conceptualisation is called $21^{\text {st }}$ century skills; others include "generic skills", "key attributes", "core competences" and "graduate attributes" (Virtanen \& Tynjälä, 2018; Oliver \& St. Jorre, 2018; Viinikka \& Ubani, 2019). The theoretical approaches on learning behind the $21^{\text {st }}$ century skills can be identified include aspects from problem-based learning (Boud \& Feletti, 1991) social learning theory (Bandura, 1977), cognitive flexibility theory (Scott, 1962; Spiro, Coulson, Feltovich, \& Anderson, 1988) and networked learning theory (Illich, 1971; Siemens, 2005), for example. The 21 ${ }^{\text {st }}$ century learning approach can also be viewed as a revision or reorganisation of the existing educational theories. For example, Anderson and Krathwohl (2001) argued for the development of lower order thinking levels (remembering) and middle order thinking levels (understanding and applying) from Bloom 's taxonomy at the same time with higher order thinking levels (evaluating and creating) (Bloom, Krathwohl, \& Masia, 1972): to teach the students factual knowledge and skills in order to develop their own thinking for the 21st century demands (Silva, 2008).

In the literature, there exists several models for 21 ${ }^{\text {st }}$ century skills (Dede, 2009; Geisinger, 2016; Ananiadou \& Claro, 2009; Soland, Hamilton, \& Stecher, 2013). The different models have been devised to complement the skill set identified as integral in the literature (Dede, 2009). In general studies have highlighted, for example, skills such as learning to learn, enquiry, communication, information 
and ICT literacy, citizenship, life and career, personal and social responsibility, learning and innovation skills, critical thinking, problem solving, communication technology, collaboration, creativity, social and cross-cultural interaction, productivity, accountability and knowledge creation as integral skills for a 21 st century citizen (Darling-Hammond, 2006; Newton \& Newton, 2014; Niemi et al., 2014; Niemi \& Multisilta, 2016; Niemi, Niu, Vivitsou, \& Li, 2018; Wang, Lavonen, \& Tirri, 2018).

In this study, we use the framework by The Partnership for $21^{\text {st }}$ Century Skills (P21). P21 is a network of almost 30 major businesses and education groups and supported by the United States Conference of Mayors. They have outlined nineteen $21^{\text {st }}$ century skills (Table 1) into the following three categories: (1) learning and innovation skills, (2) information, media and technology skills and (3) life and career skills (Partnership For 21st Century Skills, 2009). The full list of skills used in this study is described in table 1. In order to highlight the specific demands with regards to multiculturalism, religions and diverse worldviews in public education identified in the literature (OSCE/ODIHR, 2007; Jackson, 2014), a fourth skill category called (4) dialogue skills (Viinikka \& Ubani, 2019) was added in the framework by the project this study belongs in.

The adjustments of the framework are based on the characteristics and demands placed on RE in Finnish public education. As has been stated, generally in public education in the Nordic countries, the subject of RE has been given the task to provide the students with tools to navigate in a multicultural and diverse society (Biseth, 2009; Ubani, 2018, 2019). In Finland, RE is a compulsory "weakconfessional" subject in public education: the subject emphasises the development of students' own view of life, and does not include faith-formation or devotional aspects (Ubani \& Tirri, 2014; Kallioniemi \& Ubani, 2016) but the students are divided into separate lessons based on their own religion. The content emphasises the tradition of the student but also focuses on questions of inter-religious and intra-religious diversity, non-religious convictions and dialogue (NCCBE, 2014). The subject is an integral part of comprehensive public education: for instance, recently, the subject's merits in the PISA achievements of Finnish public education have been elaborated (Kallioniemi \& Ubani, 2016).

Competence in classroom interaction concerning inter-religious and intrareligious dialogue along with recognition of non-religious convictions in instruction is a core skill for RE teachers in public education today (Jackson, 2014). The professional RE teacher needs to have competence in the subject, competence in teaching methods and communicative competence in the classroom and school (Bakker \& Heimbrock, 2007). Naturally, the current social and cultural context is determining the characteristics of the professional conduct of an RE teacher, but one of the main tools for developing the RE teachers' quality is supported by academic teacher education by enhancing the teachers' ability to reflect their practices (Räsänen, Ubani, Ziebertz, \& Riegel, 2009). Ideally, modern RE can develop the "equal togetherness" through discussions with people from different faiths and religions (Riitaoja \& Derwin, 2016). However, in order to provide a "safe space" (Jackson, 2014) for examining 
religions, worldviews and convictions, the teacher also needs to be aware of their own convictions and conceptions of religion and non-religious worldviews (Cox, 1983). Subsequently, to cover the different aspects inherent in dialogue in educational practice, we have distinguished between generic dialogue skills, dialogue education skills and intra-personal dialogue skills in the fourth skill category. The theoretical basis is from the work of Burbules (1993) (see also Riitaoja \& Derwin, 2016) and Jackson (2014).

For the same reason that we added dialogue skills as a category, we added religious literacy as a type of information, media and technology skill. Religious literacy refers to an understanding of the grammars, rules, vocabularies and narratives underpinning religions and beliefs (Dinham \& Shaw, 2017). In different forms of knowledge about religions along with their symbols, the global, societal, communal and personal significance is shared as a core objective of religious education in the public schools of Western societies (Schreiner, 2007).

The RE teachers' and student teachers' professionalism and their development have been researched before in Finland (Ubani, 2012a, 2012b, 2016; Kallioniemi, 1997; Hella, 2007) and internationally (Räsänen \& Ubani, 2009; Ziebertz \& Riegel, 2009; Bakker \& Heimbrock, 2007). For instance, Räsänen's and Ubani's (2008) comparative study showed how Finnish RE teachers when compared to RE teachers in many European countries were particularly open to dialogue and inclusive regarding the recognition of multiculturalism, pluralisation and diversity. In his review study, Ubani (2016) discussed his observations on RE student teachers' professional development in teacher education in terms of orienting towards the RE profession, developing professional ethics, an increasing sense of efficacy and processing conviction and calling. According to him, during teacher education, the student teachers' conceptions about competence from personal and individualistic views (Ubani, 2011) develop into more professional and pedagogical conceptualisations (Ubani, 2012b). For example, the importance of knowledge expertise seems to increase during the progress of the studies (Ubani, 2012a) and the emphasis on empathy is transforming towards a student-centred pedagogy (Ubani, 2011). In general, the student teachers stress mastery of the subject matter, empathy and interaction skills as the three most important characteristics of a competent RE teacher (Ubani, 2012a). In addition to the instruction given in teacher education, the RE in-service teachers draw from different sources to their professional reflection, such as the previous experiences of an RE teacher and situational sources such as peer-discussions and life issues (Ubani, 2015, 2016).

Another study showed that, in contrast to other students, the RE student teachers argued explicitly that the teacher should be aware of their own religious identities and value positions and be able to discuss different worldviews with pupils (Tirri \& Ubani, 2014). Recently, Viinikka and Ubani (2019) studied the expectations of eight RE student teachers in light of $21^{\text {st }}$ century skills during their major and pedagogical studies. RE student teachers reflected their expectations via how their interpretations are about a competent RE teacher today and in the future. They expected religious literacy and dialogue skills to 
develop during their theological studies (major studies) and social skills and also dialogue skills were expected to develop especially during the pedagogical studies.

\section{Research procedures}

The data included both quantitative questionnaire and qualitative interview data. The questionnaire $(\mathrm{N}=43)$ was collected in autumn 2018 from RE student teachers at the University of Eastern Finland and University of Helsinki. The respondents - aged 18-55 - included 12 male and 30 female participants; one reported "other" as their gender. In the questionnaire, they were asked to evaluate the importance of $21^{\text {st }}$ century skills for the success of an RE teacher in the next 20-30 years. Table 1 shows the skills which were asked in the questionnaire. The questionnaire used a 5 point Likert scale $(1=$ not so important and $5=$ very important). From this data, the means and the standard deviations were analysed.

Table $1.21^{\text {st }}$ century skills in this study

\begin{tabular}{|c|c|}
\hline 1. Learning and Innovation Skills & 2. Information, Media and Technology Skills \\
\hline Critical thinking & Information literacy \\
\hline Creativity & Media literacy \\
\hline Collaboration & Technology literacy \\
\hline Communication & Religious literacy \\
\hline \multicolumn{2}{|l|}{ Learning to learn } \\
\hline 3. Life and Career Skills & 4. Dialogue Skills \\
\hline Flexibility & Generic dialogue skills \\
\hline Leadership & Dialogue education \\
\hline Initiative & Dialogue self-skills \\
\hline Productivity & \\
\hline Social skills & \\
\hline Accountability & \\
\hline Citizenship & \\
\hline Combining life and career & \\
\hline $\begin{array}{c}\text { Global responsibility and sustainable } \\
\text { development }\end{array}$ & \\
\hline
\end{tabular}


The second set of the data was the interview material. The eight participants were RE student teachers in the programme of RE teacher education at the University of Eastern Finland (Table 2). They had also completed the quantitative questionnaire. The participants consisted of five female and three male students aged between 19 and 29. Four of them started their theological studies in autumn 2018. The other four students were in the beginning of their pedagogical studies (the second year in their pedagogical studies). The interviews lasted between 1 and 1 1/2 hours.

Table 2. Gender, code and age of interviewees

\begin{tabular}{|c|c|c|}
\hline Gender & Code & Age \\
\hline Male & 001 & 20 \\
\hline Female & 003 & 19 \\
\hline Female & 005 & 24 \\
\hline Male & 011 & 29 \\
\hline Female & 018 & 28 \\
\hline Female & 019 & 21 \\
\hline Male & 020 & 23 \\
\hline Female & 023 & 23 \\
\hline
\end{tabular}

In the semi-structured interviews (see the structure of interviews Viinikka \& Ubani 2019) eight RE student teachers evaluated the competence demands in the work of an RE teacher today and in the future in light of the P21 framework. For instance, the students were asked to reflect which $21^{\text {st }}$ century skills they perceived to be integral in the professional practice of the RE teacher now and whether some of the skills would be even more important in future. The participants were given the $21^{\text {st }}$ century skills table to support their elaboration (Table 1.)

The content analysis (Cohen, Manion, \& Morrison, 2003) was done deductively with the use of the $21^{\text {st }}$ century skills listed hereinabove. In the first phase, the statements of the RE student teachers concerning the skills were identified in the data. Thereafter, the data was reread. In the next phase, the statements were placed into the respective categories of $21^{\text {st }}$ century skills: 1) Learning and Innovation skills, 2) Information, Media and Technology Skills, 3) Life and Career Skills and 4) Dialogue Skills. The number interviewees who mentioned each skill is reported in the results as frequencies. Finally, frequencies were listed into the two groups; perceptions about the demands now and the skills that would be in even higher demand in the future for the conduct of an ideal RE teacher (Table 4, 5, 6, 7). Subsequently, the frequencies in the first category 
"now" mean that RE student teachers think that those skills are part of the competence of an RE teacher today. The "future" category means that some RE student teachers underlined some of the $21^{\text {st }}$ century skills in the competence of an RE teacher in the future. The results section combines results from both questionnaires and interviews. An inter-rater reviewer was used for the reliability of the analysis. The inter-rater reliability was an exceptional 1.00 but this was because the semi-structured interview used the P21 framework as a basis.

\section{Results}

Overview of the results concerning 21st century skills

This section begins with a general overview of the results. After the overview the participants' perceptions in each of the four categories of $21^{\text {st }}$ century skills are presented. In general, the RE student teachers considered all of the listed $21^{\text {st }}$ skills as important for the ideal RE teacher in the next 20-30 years. Figure 1 shows the four $21^{\text {st }}$ century skills main category and the means of the student answers in the questionnaires. In general, on a 5-point Likert scale, the means were quite similar and high. When compared, dialogue skills $(M=4,674)$ were emphasised the most while life and career skills $(M=4,153)$ less so among the student teachers. The interview material also confirmed that the RE student teachers considered all 21 different skills as quite equally important: the total sums of frequencies were distributed evenly between the skill sets (Table 4 and Table 5). Life and career skills $(f=31)$ and dialogue skills $(f=15)$ were also seen as a relevant part of the competence of an RE teacher.

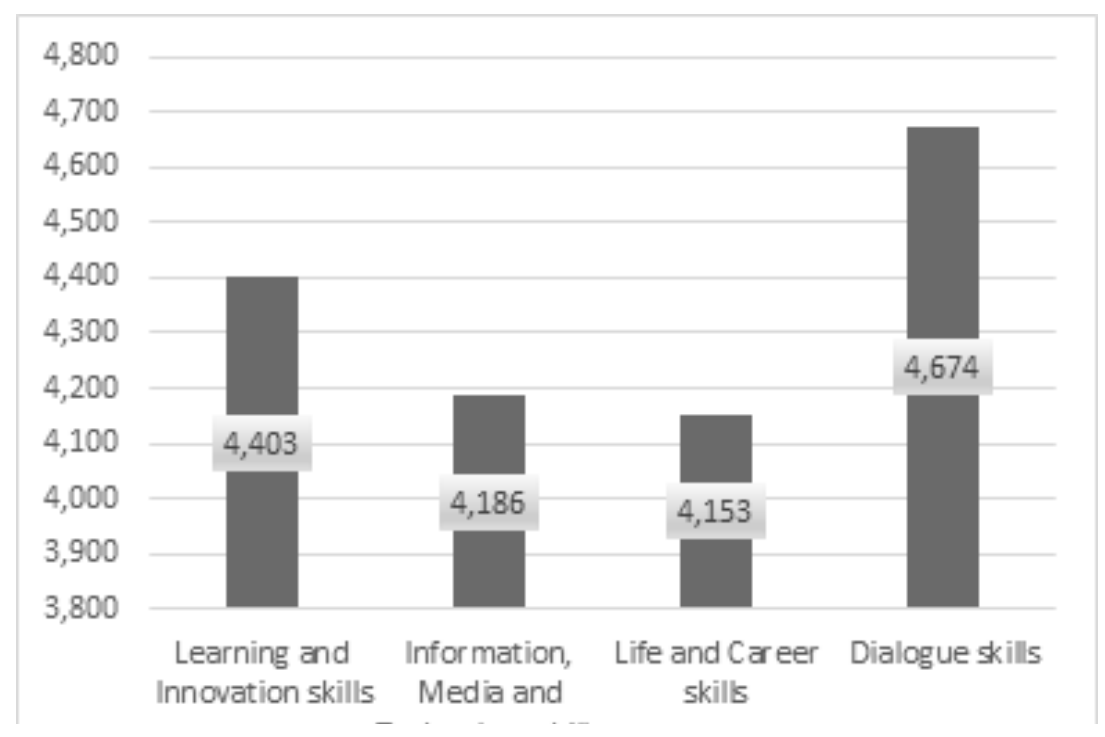

Figure $1.21^{\text {st }}$ century skills categories and means

Table 3. shows the students' means and standard deviations concerning the importance of each of the 21st century skills in the task of the RE teacher in the next 20-30 years. Based on both the quantitative and qualitative analyses, the RE student teachers thought that learning to learn $(M=4,349 ; f=8)$, communication $(M=4,674 ; f=6)$ and critical thinking $(M=4,512 ; f=4)$ were relevant skills for an 
RE teacher now and in the future. Especially all the literacy skills were highlighted in the interviews: they were thought to help with different changes which are going on all the time in society and throughout the world. Religious literacy $(M=4,279 ; f=7)$ was seen as a crucial part of the competence of an RE teacher. In the category of life and career skills were social skills $(M=4,605 ; f=6)$ and accountability $(f=6)$ the most emphasised skill for a successful RE teacher. However, the students emphasised understanding plurality $(M=4,651)$ the most from that skill domain (Figure 4). The RE student teachers also discussed how social skills would always be a part of RE teacher competence because the teacher works and interacts with other people. In addition, dialogue skills $(M=$ $4,674)$ in figure 1 and especially generic dialogue skills $(f=7)$ in the table 7 were seen now and in the future as a remarkable tool in teaching religion. The RE student teachers elaborated that there would be more and more people with diverse views and religions in a classroom and the teacher would need to have skills to teach and handle the situation.

Table 3. Skill, mean and deviation

\begin{tabular}{|c|c|c|}
\hline Skill & $\mathbf{M}$ & SD \\
\hline Dialogue skills & 4,674 & 0,644 \\
\hline Initiative & 4,209 & 0,861 \\
\hline Using technology & 4,093 & 0,868 \\
\hline Leadership & 3,605 & 1,137 \\
\hline Flexibility & 4,395 & 0,660 \\
\hline Creativity and innovation & 4,302 & 0,708 \\
\hline Self-direction & 4,209 & 0,709 \\
\hline Taking into account social and cultural factors & 4,419 & 1,349 \\
\hline Productivity & 3,651 & 1,193 \\
\hline Communication & 4,674 & 0,644 \\
\hline Religious literacy & 4,279 & 0,854 \\
\hline Social skills & 4,605 & 0,728 \\
\hline Utilising information & 4,326 & 0,837 \\
\hline Making results & 3,070 & 1,121 \\
\hline Global responsibility and sustainable development & 4,167 & 0,710 \\
\hline Collaboration & 4,186 & 0,546 \\
\hline Using media & 4,302 & 0,708 \\
\hline Problem solving & 4,395 & 0,821 \\
\hline
\end{tabular}




\begin{tabular}{|c|c|c|} 
Critical thinking & 4,512 & 0,736 \\
\hline Knowledge/Information searching skills & 4,558 & 0,590 \\
\hline Expertise in Theology & 3,558 & 1,736 \\
\hline Understanding plurality & 4,651 & 0,650 \\
\hline Noticing the effects of teaching on society & 4,512 & 0,592 \\
\hline Learning to learn & 4,349 & 0,650 \\
\hline Combining life and career & 4,357 & 0,846 \\
\hline
\end{tabular}

\section{Learning and Innovation Skills}

Next, the RE student teachers' perceptions on all four categories were examined. As can be seen in figure 2, the student teachers perceived all the sub-skills from the category of learning and innovation skills as important. They perceived critical thinking $(M=4,512 ; S D=, 736)$ creativity and innovation $(M=4,302 ; S D=$ ,708) collaboration $(M=4,186 ; S D=, 546)$ communication $(M=4,674 ; S D=, 644)$ and learning to learn $(M=4,349 ; S D=, 650)$ as important in the competence of an RE teacher today and in the future: among these skills, especially those referring to teamwork and interaction were stressed.

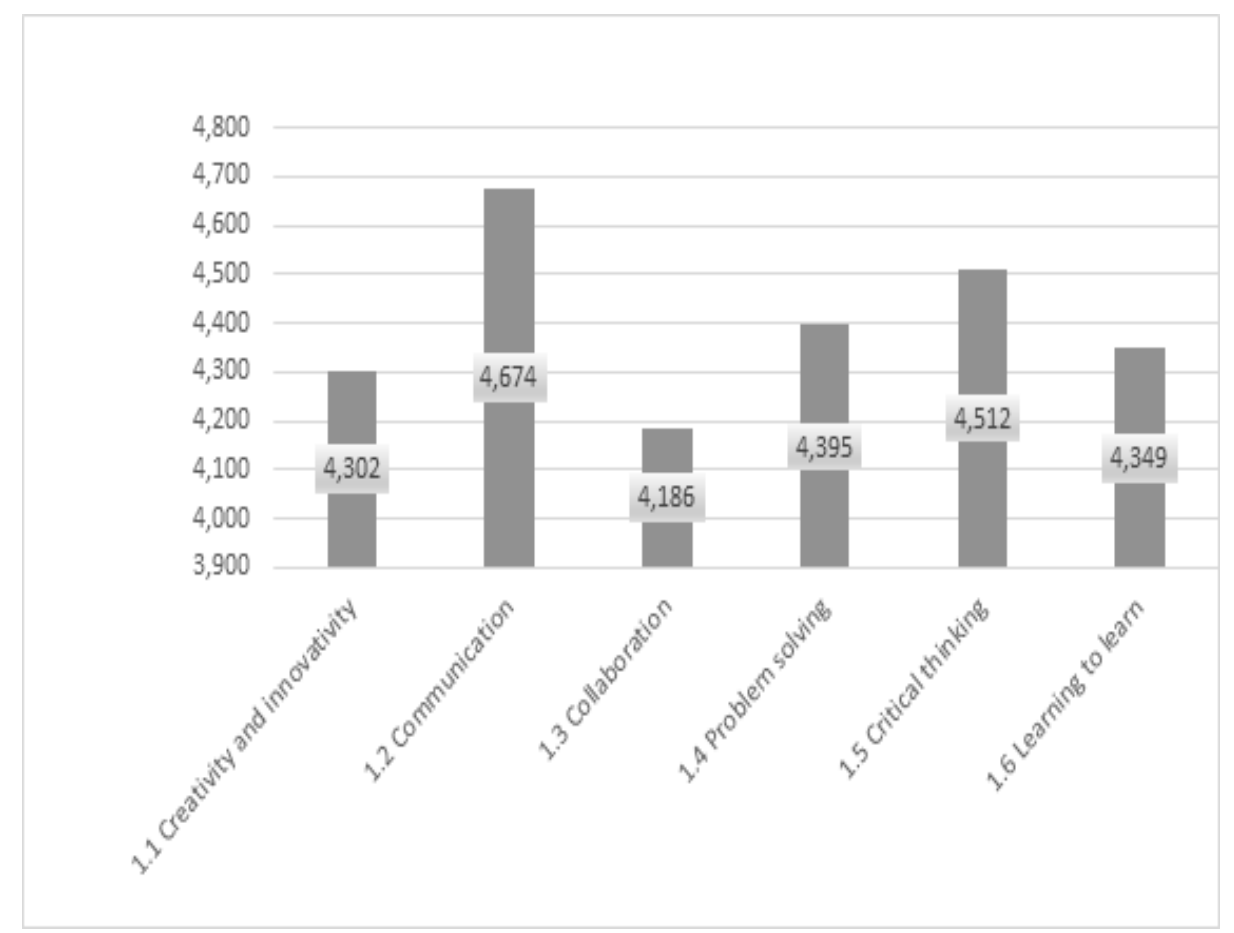

Figure 2. Learning and Innovation Skills in the competence of an RE teacher

The interviews confirmed that the RE student teachers viewed all the learning and innovation skills as quite important (Table 4). Again, the skills related to teamwork and interaction were emphasised. However, in contrast to the 
emphasis in the questionnaire, all interviewees mentioned learning to learn $(f=8)$ as part of the current professionalism of an RE teacher. Among the students, learning to learn was seen to be a constantly evolving skill because of new scientific findings for instance on learning:

"There will always be better ways to learn and teach, scientific findings. The field of research must be followed so that you can develop your teaching and yourself as a teacher." (Man 001, 20 years).

"Seeing learning as a lifelong process is important. The teacher is never ready." (Woman 023, 23 years).

Table 4. Importance of Learning and Innovation Skills in the competence of an RE teacher

\begin{tabular}{|c|c|c|}
\hline $\begin{array}{c}\text { Learning and } \\
\text { Innovation Skills }\end{array}$ & Now & Increases in future \\
\hline Critical thinking & 4 & 3 \\
\hline Creativity & 4 & 2 \\
\hline Collaboration & 5 & 3 \\
\hline Communication & 6 & 3 \\
\hline Learning to learn & 8 & 1 \\
\hline Total sum (f) & $\mathbf{2 7}$ & $\mathbf{1 2}$ \\
\hline
\end{tabular}

About half of the participants brought up critical thinking $(f=3)$, collaboration $(f=$ 3 ) and communication $(f=3)$ as a skill which demand would increase in the future. Among the students, critical thinking was thought to be integral in distinguishing true information from false information. The reasoning was that nowadays there were more different people groups (pupils, parents, colleagues and authorities) who a RE teacher is collaborating with than in the past. Therefore, communication and collaboration in the work of an RE teacher were also seen as relevant in the future by a few of the students.

"Teaching is not changing at the core, for example, social interaction is always important." (Man 001, 20 years).

"Of course, collaboration is because there are bigger masses of people who you are working with." (Woman 003, 19 years).

Again, half of the participating RE student teachers perceived creativity $(f=4)$ as important in the work of an RE teacher currently. For instance, creativity was perceived as the enabling ability so that one would be able to combine skills flexibly to meet changing situations: 
"Immediately you can throw creativity because the teaching methods can be so different nowadays." (Woman 003, 19 years).

"Creativity and that [the teacher] is inspiring. It is easy to approach. Concerning the future, you don't know what the teaching is. Let's be in the classroom or taught, for example, through the video connection. The ability to flex itself and that you are open to all doors is important." (Woman 005, 24 years).

\section{Information, Media and Technology Skills}

The second main skill category of the 21st century skills that was studied was called information, media and technology skills. The RE student teachers considered all literacy skills important as a current and future competence in the profession of an RE teacher (Figure 3 and Table 5). Knowledge/information searching skills $(M=4,558 ; S D=, 590)$ was seen the most important skill (Figure 3). Similarly, the RE student teachers viewed utilising information $(M=4,326$; $S D$ $=, 837)$ and information literacy $(f=6)$ as an important part of RE teacher competence now. Literacy skills were seen as relevant in the future among the student teachers because for instance information and technology change and develop rapidly and continuously:

"Technology, media and information literacy will become more pronounced if the same direction continues. And I can assume that it will continue." (Woman 003, 19 years).

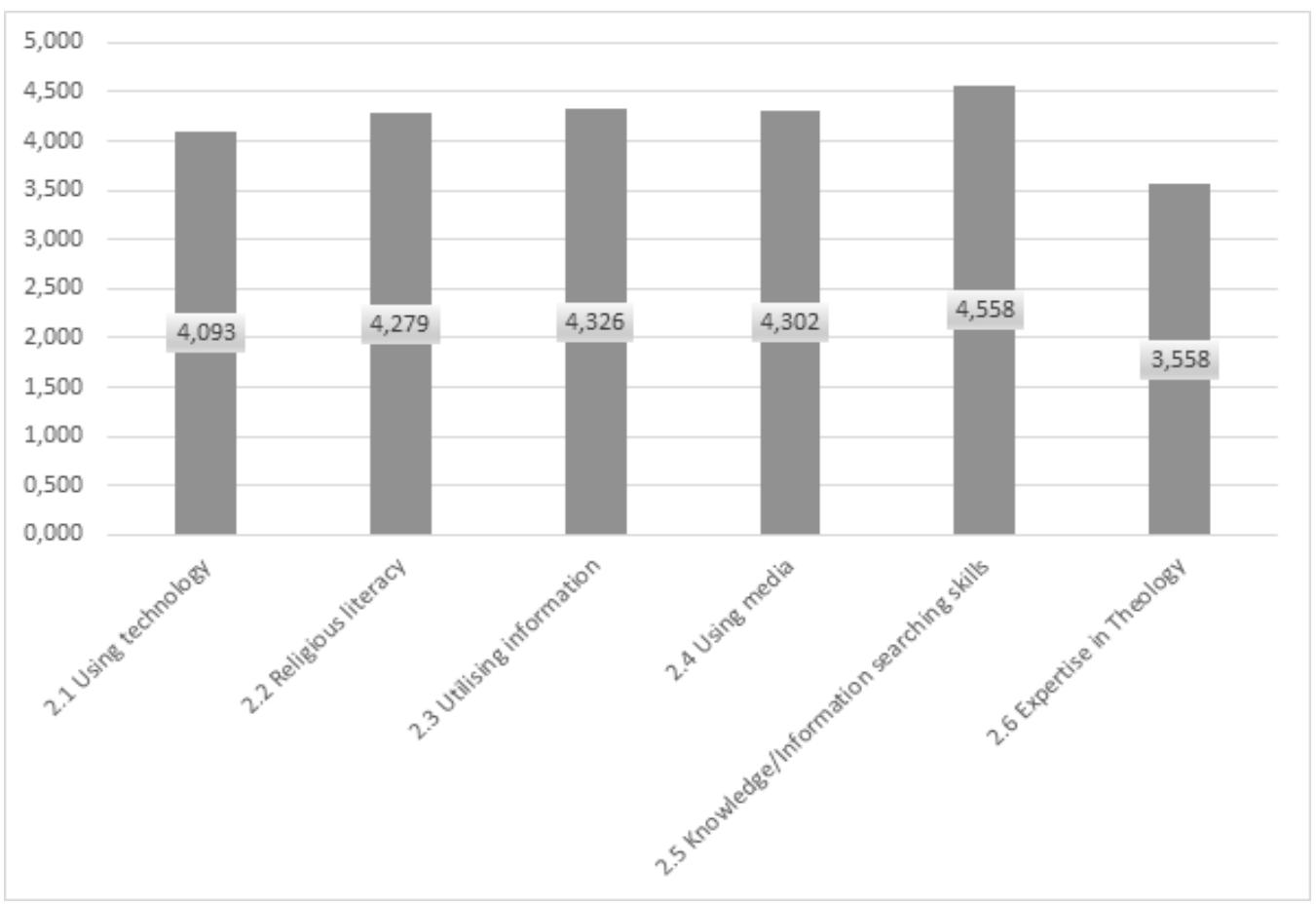

Figure 3. Information, Media and Technology Skills in the competence of RE teacher 
The RE student teachers seemed to especially emphasise the importance of technology literacy $(f=7)$ in the interviews concerning the current and future competence of RE teachers (Table 5.) As Figure 3 shows the average in the perceptions with regards to using technology is quite good $(M=4,093 ; S D=, 868)$. The RE student teachers seemed to think that technology would play an important role nowadays in the work of the RE teacher and, among other things, that is why the skills should be learned and developed. The RE student teachers thought that in the future more novel, developed technologies would appear:

"Technology literacy is a sustainable and necessary process that always comes up. The future is completely open in this respect. You can't stay behind." (Man 001, 20 years).

"Technology literacy, because almost everything today is electronic." (Woman 003, 19 years).

"Of course, the ability to use technology. That's when we're doing the digital leap and the like now." (Woman 023, 23 years).

Table 5. Importance of Information, Media and Technology Skills in the competence of RE teacher

\begin{tabular}{|c|c|c|}
\hline Information, Media and Technology Skills & Now & Increases in the future \\
\hline Information literacy & 6 & 4 \\
\hline Media literacy & 7 & 4 \\
\hline Technology literacy & 7 & 6 \\
\hline Religious literacy & 7 & 4 \\
\hline Total sum (f) & $\mathbf{2 7}$ & $\mathbf{1 8}$ \\
\hline
\end{tabular}

Based on the questionnaire, the RE student teachers perceived using media ( $M=$ 4,302 ; $S D=, 708$ ) as a key skill (Figure 3) in the competence of the RE teacher. The RE student teachers often connected media literacy $(f=7)$ with technology in interviews. For instance, the students stressed that in the task of an RE teacher, one needed to be able to understand and use different sources of media:

"Technology will evolve. The news will change. There may be more fake news releases. Maybe some of them can be cut off." (Man 020, 23 years).

As expected, the RE student teachers highlighted religious literacy $(M=4,279 ; S D$ $=, 854)(f=7)$ (Figure 3 and Table 5) as the skill needed today and in the future. This form of literacy can be perceived as a key competence in RE. The RE student teachers maintained that the RE teacher could not be competent without religious literacy now and in the future:

"Religious literacy is one that is a core of profession of RE teacher. Social skills are also important. I would dare to argue that media literacy 
should now be obvious already, because so many religions are discussed different way in the media." (Woman 003, 19 years).

"Especially in primary school, the teacher creates a worldview for young people. Tools for civilisation can be given to young people." (Man 001, 20 years).

\section{Life and Career Skills}

The third skill category was called 'life and career skills'. Here again, the RE student teachers perceived all skills as quite important in the successful management of the occupation of a RE teacher today and in the future. As Figure 4 shows that many of the averages of all sub-skills were quite high. The highest average was understanding plurality $(M=4,651 ; S D=, 650)$ which can be perceived to be connected with many skills and social skills $(M=4,605 ; S D=$ ,728). Furthermore, social skills were mentioned in six interviews (Table 6). Social skills were seen as the relevant part of RE teacher competence because the students expected to work with different people who have diverse opinions and views. The RE student teachers described how there were many kinds of topics in religion lessons and how the teacher needed social skills in handling the different viewpoints:

"Social skills have been highlighted recently. Many people may come to discuss, to challenge your views concerning religions. You have to be prepared to face different opinions." (Man 001, 20 years).

"That can meet different people. Groups and people are different. Able to give everyone what they need." (Woman 023, 23 years).

"There will always be social skills and interaction at least in some form important." (Man 020, 23 years).

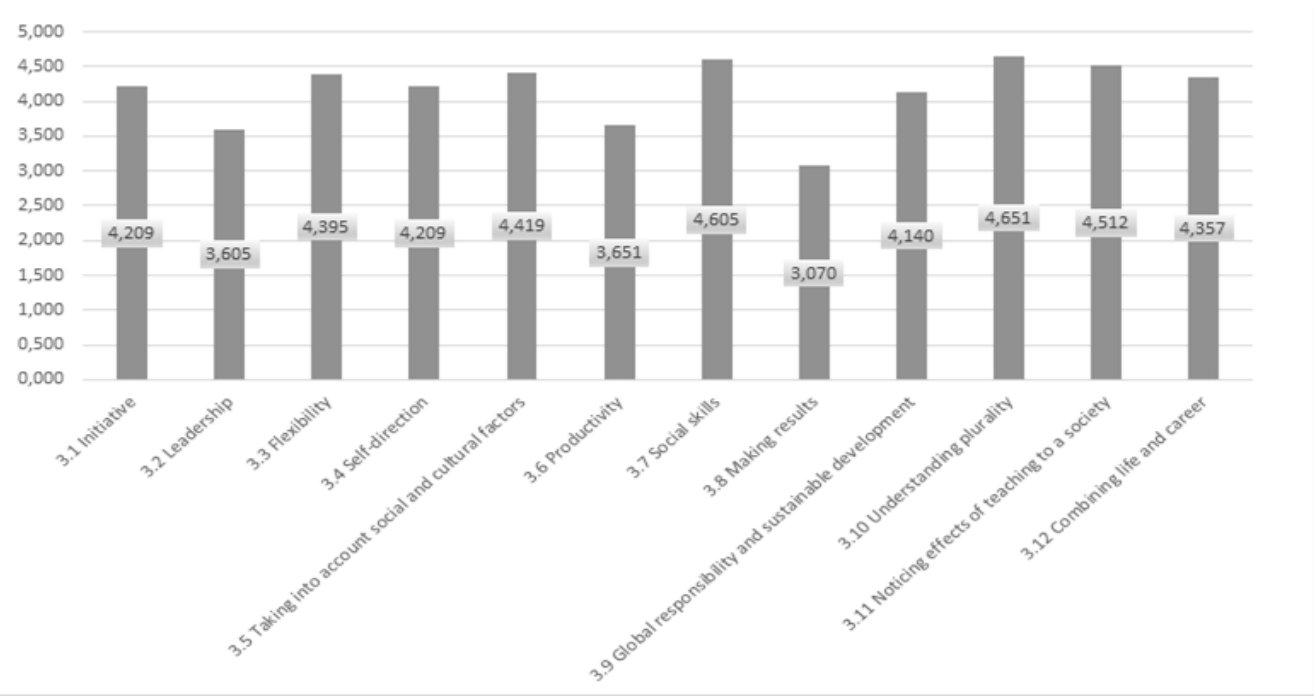

Figure 4. Life and Career Skills in the competence of an RE teacher 
The student teachers also emphasised noticing the effects of teaching on society $(M=$ $4,512$; $S D=, 592)$ (Figure 4) and citizenship $(f=4)$ (Table 6) - this implies that RE student teachers were aware that the professional work of an RE teacher could have an effect on society. In addition, another aspect that was emphasised, taking into account social and cultural factors $(M=4,419$; $S D=1,349)$, could be seen to be connected to the aspects in society. Concretely, the interviewees discussed a lot on how the work of an RE teacher affected the youth and, through them, society.

In addition, the RE student teachers perceived accountability $(f=6)$ (Table 6) as a relevant skill in the competence of an RE teacher currently. They described accountability to mean that the RE teacher would be accountable for their work and should know about that. It was considered as important that the teacher strove for transparency and did not hide their failures in work.

In the interviews, the participant RE student teachers discussed how flexibility $(M=4,395 ; S D=, 660)$ and $(f=4)$ was a central skill considering the competence of an RE teacher now and in the future because the teacher had to have many things under control:

"In the world of teaching, everything is constantly changing, for example, doctrines and regulation." (Man 001, 20 years).

"Flexibility in the way that you have to listen to the students and be present and follow the way the class situation changes due to different things. Accepts that things are not always going as planned." (Woman 023, 23 years).

Table 6. Importance of Life and Career Skills in the competence of an RE teacher

\begin{tabular}{|c|c|c|}
\hline Life and Career Skills & Now & Increases in the future \\
\hline Flexibility & 4 & 1 \\
\hline Leadership & & 2 \\
\hline Initiative & 1 & 1 \\
\hline Productivity & 2 & 4 \\
\hline Social skills & 6 & 1 \\
\hline Accountability & 6 & 4 \\
\hline Citizenship & 4 & \\
\hline Combining life and career & 4 & 3 \\
\hline $\begin{array}{c}\text { Global responsibility and sustainable } \\
\text { development }\end{array}$ & 4 & $\mathbf{1 6}$ \\
\hline Total sum (f) & 31 & \\
\hline
\end{tabular}


The RE student teachers discussed that productivity $(M=3,651 ; S D=1,193)$ and $(f$ $=2$ ) was important: for instance, the teacher was to produce teaching materials, and the teaching itself has to be productive. The teacher was considered to be responsible for their part for the learning of the students. Moreover, making results $(M=3,070 ; S D=1,121)$ can be seen as a part of productivity (Figure 4 ). The teacher was meant to support students in their development to self-guided and responsible people and learners:

"Young people are supposed to work and learn for themselves." (Man 001, 20 years).

The participating RE student teachers also discussed that, in the work of the teacher, it would be important to learn to follow a combined life and career in a healthy way for career resiliency. Among the students, the skill combining life and career $(M=4,357 ; S D=, 846)$ and $(f=4)$ were discussed in connection with the fact that RE student teachers saw the professional role of the teacher in people's minds to be the same at work and in their spare time:

"The teacher is the title. People remember you as a teacher in every place." (Man 001,20 years).

RE student teachers described that it was possible to deal with global issues and challenges smoothly in the RE lessons. Therefore, global responsibility and sustainable development $(M=4,140 ; S D=, 716)$ and $(f=4)$ was emphasised as the skill in the competence of an RE teacher:

"I have personally found that's an important part of work of an RE teacher. Bringing up the sustainable development because we can influence a lot of views of children towards the world. There may be a long period of thought discussion, which may not be the case, for example, in mathematics. The climate change can be taken as a theme for the lesson." (Woman 019, 21 years).

"Global responsibility and sustainable development. I guess it will become more important in the future." (Woman 003, 19 years).

Figure 4 shows that the RE student teachers thought that leadership $(M=3,605$; $S D=1,137)$ was an important skill. Table 6 shows that in the interviews leadership was particularly relevant to the competence of an RE teacher in the future $(f=2)$. The RE student teachers thought that leadership could take different forms and, therefore, the teacher could have different roles depending on the situation. Leadership could take form, for instance, in terms of a coach:

"Maybe leadership will change, but it will not disappear. There may have been more talk the teacher today, not a leader, but the coach." (Woman 003, 19 years). 


\section{Dialogue Skills}

The final and fourth category was called dialogue skills. Table 7 shows that RE student teachers $(f=7)$ thought that especially the importance of generic dialogue skills was integral in the competence of an RE teacher. Furthermore, in the questionnaire Dialogue skills $(M=4,674 ; S D=, 644)$ was emphasised most (Figure 1) from the four main categories by the students.

Table 7. Importance of Dialogue Skills in the competence of an RE teacher

\begin{tabular}{|l|c|c|}
\hline Dialogue Skills & Now & Increases in the future \\
\hline Generic dialogue skills & 7 & 2 \\
\hline Dialogue education & 4 & 1 \\
\hline Dialogue self-skills & 4 & \\
\hline Total sum (f) & $\mathbf{1 5}$ & $\mathbf{3}$ \\
\hline
\end{tabular}

In the interviews, the RE student teachers discussed how generic dialogue skills ( $f$ $=7)$ could help the RE teacher work in a classroom where diverse views existed. The plurality of society was used as an argument here. Both generic dialogue skills and dialogue education $(f=4)$ were seen as important tools to be able to teach religion in a relevant manner today:

"Compared to the past, dialogue skills are now essential. So many different beliefs, values, etc." (Woman 003, 19 years).

The interviews indicated that the RE student teachers perceived dialogue to involve many dimensions. They discussed, for instance, how dialogue self-skills ( $f$ $=4$ ) could help with the conscious use of your own views and beliefs in a competent manner for educating the students. Furthermore, dialogue skill was an important tool for professional development. The students repeatedly maintained that the teacher would never be ready and that it was always possible to develop oneself. There reflection was seen as the key tool in personal development:

"However, you have to understand how your personality affects your teaching." (Woman 019, 21 years).

\section{Conclusion}

This article has focused on what RE student teachers perceive as the core skills of an ideal RE teacher in the next 20-30 years. Based on the results, RE student teachers perceived all kinds of interaction skills as an essential part of RE teacher competence in the future along with dialogue skills. RE student teachers also emphasised learning and critical thinking skills as the core skills of a successful RE teacher in the future. Mishra and Mehta (2016) found corresponding results from their studies teachers' views about the necessary skills in the future. In that study, teachers emphasised the importance of meta knowledge (e.g. creativity, 
and problem solving skills, communication and collaboration) and humanistic values (e.g. life/job skills, emotional/ethical awareness).

Among the student teachers studied here, all the different literacy skills (information, media, technology and religious) were emphasised as the core skills of a successful RE teacher in the future. The RE student teachers reasoned that literacy skills help them to cope with constant change and uncertainty, e.g. technological change, the rapid renewal of knowledge, increasing diversity in the society and the impact of media. Religious literacy was considered as a key skill in the competence of the RE teacher. The participants also brought up the requirements of curriculum and the nature of RE as a school subject. For instance, a lot of information and material for teaching is online; the teacher needs technology skills for using ICT in the classroom. Furthermore, the RE student teachers saw that RE had a social and cultural impact via teaching children and youth so citizenship was also one of the core skills concerning the successful RE teacher in the next 20-30 years. The results of this study are consistent with the skill-acquisition expectations of RE student teachers of their academic studies - their expectations of professional development are connected to their perceptions of the task requirements (Viinikka \& Ubani 2019). However, the limitations of this study calls for more research on the topic. One of the concerns is the possible dissonance between somewhat idealistic conceptions of the students and the reflection in the actual praxis. Therefore, in order to develop research-based teacher education in light of the $21^{\text {st }}$ century skills, both the perceptions of in-service teachers concerning their praxis and the perceptions of pre-service teachers during their teaching practice should be further examined.

It should be added here that, in addition to the political and economic objectives behind the emphasis on new generic skill sets (Silva, 2008), there have been some concerns and criticisms raised over the focus on $21^{\text {st }}$ century skills in public education. It has been argued that, for example, critical thinking, problem solving, information literacy, global awareness as well as thinking analytically and creatively have been taken into account from educated and cultured citizens for decades already (Rotherham \& Willingham, 2009); even Plato discussed different kinds of intelligence already at the beginning of the Common Era (Rotherham \& Willingham, 2009; Silva, 2008). There has also been concerns over the situation that focusing on $21^{\text {st }}$ century skills in schools distracts education from more important tasks of education such as teaching the core content to students (Silva, 2008; Suto \& Eccless, 2014).

On the other hand, we think that the education of teachers of RE should be increasingly aware of the subject's potential contribution to the development of several skills and of the subjects' broader relevance and implications in societies today and in the future and, therefore, conceptualisations such as P21 should be implemented more widely in education. For instance, UNESCO (2016) in the teacher's guide on the prevention of violent extremism, addresses religion and beliefs as a subject among others like citizenship, history, languages and art which can foster awareness about and respect for diversity within communities. 
Education on religion and beliefs can provide opportunity to explore different values and belief system. The grand challenge there is the learners learn to explore their own values and opinions in a reflective way learning to live together and respect for human rights and diversity (UNESCO, 2016, 31, 35-39). Gaining the skills to understand different religions and worldviews in dialogical, critical and reflective manner is essential for developing respect for diverse citizenship, social harmony and in the prevention violent extremism (see, e.g. NCCBE, 2014; Niemi, Kallioniemi, \& Ghosh, 2019). Public schools should represent modern democratic societies where religions and worldviews are handled, discussed and reflected openly in a constructive way so that education would provide comprehensive tools for navigating successfully in societies today and in the future (Ghosh, 2018).

\section{About the authors:}

Kaisa Viinikka is a ThM, MSS and RE teacher. She is a PhD student and conducting research on a "21st century skills, multiple literacies and developing RE teacher education" project at the University of Eastern Finland. Her research interests are focusing on $21^{\text {st }}$ century skills, teacher education and teaching.

Martin Ubani is a professor of religious education at the schools of Theology and the Applied Science of Education and Teacher Education, University of Eastern Finland. His research focuses on religion and education, religion in multicultural education, classroom research and teacher education. He is the leader of the research project.

Tuuli Lipiäinen, M.Ed, is a PhD student at the University of Helsinki. Her research interests include 21st century skills, teacher education and integrated religious education. She also works in the project "21st century skills, multiple literacies and developing RE teacher education".

Arto Kallioniemi is a Professor of Religious Education at the Faculty of Educational Sciences, University of Helsinki. He specializes in religious education and worldview education and subject teacher education. Furthermore, his interested in issues related to inter-worldview dialogue and human rights. He has a number of publications (also books and textbooks) in religious education. Kallioniemi also holds the UNESCO Chair on Values, Dialogue and Human Rights.

Note: This study has received funding from the Finnish Ministry of Education as part of the project "21st century skills, multiple literacies and developing RE teacher education" (2018-2021). https://blogs.uef.fi/21skillsreteachedu-en/ 


\section{References}

Ananiadou, K., \& Claro, M. (2009). 21st century skills and competences for new millennium learners in OECD countries. OECD Education Working Papers, No. 41. OECD Publishing.

Anderson, L. W., \& Krathwohl, D. R. (2001). A Taxonomy for Learning, Teaching, and Assessing. Abridged Edition. Boston, MA: Allyn and Bacon.

Bakker, C., \& Heimbrock, H.-G. (Eds.). (2007). Researching RE teachers. RE teachers as researcher. Münster: Waxmann.

Bandura, A. (1977). Social learning theory. Englewood Cliffs, N.J.: Prentice-Hall.

Binkley, M., Erstad, O., Herman, J., Raizen, S., Ripley, M., Miller-Ricci, M., \& Rumble, M. (2012). Defining TwentyFirst Century Skills. In P. Griffin, B. McGaw, \& E. Care (Eds.), Assessment and Teaching of 21st Century Skills (pp. 17-66). Dordrecht: Springer Netherlands.

Biseth, H. (2009). Democracy and Education in a Multicultural Scandinavia: What Mandate is Designated to Educators? Intercultural Education, 20(3), 243-254.

Bloom, B. S., Engelhart, M. D., Furst, E. J., Hill, W. H., \& Krathwohl, D. R. (1972). Taxonomy of educational objectives: The classification of educational goals. Handbook I: Cognitive domain. New York: David McKay Company

Bonk, C. J., \& Graham, C. R. (Eds.). (2004). Handbook of blended learning: Global Perspectives, local designs. San Francisco, CA: Pfeiffer Publishing.

Boud, D., \& Feletti, G. (1991). The challenge of problem based learning. London: Kogan Page.

Burbules, N. C. (1993). Dialogue in Teaching: Theory and Practice. New York: Teachers College Press.

Cohen, L., Manion, L., \& Morrison, K. (2004). A Guide to Teaching Practice. 5th ed. London: Routledge.

Cox, E. (1983). Problems and possibilities for religious education. London: Hodder and Stoughton.

Darling-Hammond, L. (2006). Constructing 21 st century teacher education. Journal of Teacher Education 57(3), 300-314. doi:https:/ / doi.org/10.1177/0022487105285962

Dede, C. (2009) Comparing Frameworks for "21st Century Skills". Harvard Graduate School of Education.

Dinham, A., \& Shaw, M. (2017). Religious Literacy through Religious Education: The Future of Teaching and Learning about Religion and Belief. Religions 8(11), 1-13.

Geisinger, K. (2016). 21 ${ }^{\text {st }}$ Century Skills: What Are They and How Do We Assess Them? Applied Measurement in Education 29(4), 245-249. doi:https:/ / doi.org/10.1080/08957347.2016.1209207

Ghosh, Ratna. (2018). The Potential of the ERC Program for Combating Violent Extremism among Youth. Religion \& Education.

Griffin, P., Care, E., \& McGaw, B. The Changing Role of Education and Schools. (2012). Defining TwentyFirst Century Skills. In P. Griffin, B. McGaw, \& E. Care (Eds.), Assessment and Teaching of 21st Century Skills (pp. 17-66). Dordrecht: Springer Netherlands.

Hella, E. (2007). Variation in the understanding of Lutheranism and its implications for religious education: Meaning discernment of students and teachers in Finnish upper secondary schools. Helsinki: E. Hella.

Illich, I. (1971). Deschooling Society, Chapter 6: Learning Webs. Calder \& Boyars

Jackson, R. (2014). 'Signposts': Policy and Practice for Teaching about Religions and NonReligious Worldviews in Intercultural Education. Strasbourg, France: Council of Europe Publishing.

Kallioniemi, A. (1997). Uskonnonopettajien ammattikuva. Helsinki: Helsingin yliopiston opettajankoulutuslaitos. 
Kallioniemi, A., \& Ubani, M. (2016). Religious Education. In H. Niemi, A. Kallioniemi, \& A. Toom (Eds.), The miracle of PISA. The principles and practices of teaching and learning in Finnish schools. Second edition (pp. 179-190). Rotterdam: Sense.

Kumpulainen, K., \& Mikkola, A. (2015). Researching Formal and Informal Learning: From Dichotomies to a Dialogic Notion of Learning. International Journal for Research on Extended Education, 3(2), 50. doi:10.3224/ijree.v3i2.20889

Lankshear, C., \& Knobel, M. (2011). New literacies. Everyday practices and social learning. 3rd. edition. Berkshire: McGraw-Hill.

Lavonen, J., \& Laaksonen, S. (2009). Context of teaching and learning school science in Finland: Reflections on PISA 2006 results. Journal of Research in Science Teaching, 46(8), 922-944. https://doi.org/10.1002/tea.20339

Lonka, K. (2018). Phenomenal learning from Finland. Helsinki: Edita.

Markkola, P. (2003). Mitä on sekularisaatio? In H. Melin, \& J. Nikula (Eds.) Yhteiskunnallinen muutos. (pp. 32-47). Tampere: Vastapaino.

Mishra, P., \& Mehta, R. (2016). What We Educators Get Wrong About 21st-Century Learning: Results of a Survey. Journal of Digital Learning in Teacher Education, 33(1), 6-19. doi:10.1080/21532974.2016.1242392

National core curriculum for basic education [NCCBE] (2014). Helsinki: Finnish Agency of Education.

Newton, Lynn, D., \& Newton, Douglas, P. (2014). Creativity in 21st-century education. Prospects, 44, 575-589.

Niemi, H., Harju, V., Vivitsou, M., Viitanen, K., Multisilta, J., \& Kuokkanen, A. (2014). Digital Storytelling for 21st-Century Skills in Virtual Learning Environments. Creative Education 5, 657-671. doi:10.4236/ce.2014.59078

Niemi, H., Kallioniemi, A., \& Toom, A. (Eds.). (2006). The miracle of PISA. The principles and practices of teaching and learning in Finnish schools. Rotterdam: Sense.

Niemi, H., \& Multisilta, J. (2016). Digital storytelling promoting twenty-first century skills and student engagement. Technology, Pedagogy and Education, 25(4), 451468. doi:https://doi.org/10.1080/1475939X.2015.1074610

Niemi, H., Niu, S., Vivitsou, M., \& Li, B. (2018). Digital Storytelling for Twenty-FirstCentury Competencies with Math Literacy and Student Engagement in China and Finland. Contemporary Educational Technology, 9(4), 331-353.

Niemi, P-M., Kallioniemi, A., \& Ghosh, R. (2019). Religion as a Human Right and a Security Threat - Investigating Young Adults' Experiences of Religion in Finland. Religions. Retrieved from https://www.mdpi.com/20771444/10/1/55.

Oliver, B., \& St Jorre, T. (2018). Graduate attributes for 2020 and beyond: recommendations for Australian higher education providers. Higher Education Research \& Development, 37(4), 821-836.

OSCE/ODIHR. (2007). The Toledo Guiding Principles on Teaching about Religions and Beliefs in Public Schools. Organisation for Security and Co-operation in Europe, Office for Democratic Institutions and Human Rights. https://www.osce.org/odihr/29154?download=true

Partnership For 21st Century Skills. (2009). A Framework for Twenty-First Century Learning. Retrieved from http://www.p21.org/

Poulter, I., Rissanen, M., \& Ubani, M. (2019). Discussion. In M. Ubani, I. Rissanen, \& S. Poulter (Eds.), Contextualising dialogue, pluralism and secularisation. Cases analyses on Finnish public education. Münster: Waxmann. In press.

Riitaoja, A-L., \& Dervin, F. (2016). Interreligious dialogue in schools : beyond asymmetry and categorisation? In P. H. M. Dooly \& J. O'Regan (Eds.), Intercultural Dialogue: Questions of research, theory, and practice. London, New York: Routledge. 
Rotherham, A., \& Willingham, D. (2009). To work, the 21st century skills movement will require keen attention to curriculum, teacher quality, and assessment. Retrieved from http:/ /sttechnology.pbworks.com/f/Rotherham_BOOK_21st\%20Century\%20S kills-The\%20Challenges\%20Ahead.pdf

Räsänen, A., \& Ubani, M. (2009). Finland: The Finnish RE teacher - a modern traditionalist. In H.-G. Ziebertz, \& U. Riegel (Eds.), How teachers in Europe teach religion. An international empirical study in 16 countries. (pp. 57-68). International Practical Theology vol 12. LIT: Berlin.

Räsänen, A., Ubani, M., Ziebertz, H.-G., \& Riegel, U. (2009). Eurooppalainen uskonnonopettaja. Teologinen Aikakauskirja 114: 5 Helsinki: Teologinen julkaisuseura.

Sahlberg, P., \& Korpela, S. (2015). Suomalaisen koulun menestystarina: Ja mitä muut voivat siitä oppia. Helsinki: Into.

Schreiner, P. (2007). Religious Education in the European Context. In E. Kuyk, R. Jensen, D. Lankshear, E. Löh Manna, \& P. Schreiner (Eds.), Religious Education in Europe. Situation and current trends in schools. (pp. 9-16). Oslo: IKO.

Schön, D.A. (1983). The Reflective Practitioner. How Professionals Think in Action. New York: Basic Books.

Scott, W. (1962). Cognitive complexity and cognitive flexibility. Sociometry, 25, 405-411.

Shulman, L. (1986). Those who understand. Knowledge growth in teaching. Educational Researcher, 15(2), 4-14.

Shulman, L. 1987. Knowledge and teaching: Foundations of the new reform. Harvard Educational Review, 57(1), 1-22.

Siemens, G. (2005). Connectivism: A Learning Theory for the Digital Age. International Journal for Instructional Technology and Distance Learning, January 2005.

Silva, E. (2008). Measuring Skills for 21st Century Learning. Phi Delta Kappan, Vol 90, Issue 9, 630-635. doi: https:/ / doi:10.1177/003172170909000905

Singh, M. K. (2015). Global Perspectives on Recognising Non-formal and Informal Learning: Why Recognition Matters. Cham: Springer International Publishing.

Soland, J., Hamilton, L., \& Strecher, B. (2013). Measuring 21st century competencies: Guidance for educators. Los Angeles, CA: Asia Society/Rand Corp.

Spiro, R.J., Coulson, R.L., Feltovich, P.J., \& Anderson, D.K. (1988). Cognitive Flexibility Theory: Advanced Knowledge Acquisition in Ill-Structured Domains. Technical Report No. 441. Southern Illinois University School of Medicine: Champaign, Illinois.

Suto, I. \& Eccless, H. (2014). The Cambridge approach to 21st Century skills: definitions, development and dilemmas for assessment. IAEA Conference. Singapore, 2014. Available online: https://www.cambridgeassessment.org.uk/Images/461811the-cambridge-approach-to-21st-century-skills-definitions-development-anddilemmas-for-assessment-.pdf (Referred 30.5.2019)

Tirri, K. (2013). Education of Finnish student teachers for purposeful teaching. Journal of Education for Teaching, 39(1), 21-29.

Tirri, K., \& Ubani, M. (2014). Spirituality and education in Finland: Meeting the sociodemographic changes with empirical research. In J. Watson, M. de Souza, \& A. Trousdale. Global perspectives on spirituality and education. Routledge Research in Education 106 (pp. 71-82). Routledge: London.

Ubani, M. (2011). Expertise Over Character? The Perceptions of the Competent RE Teacher before and after Training: The Case of Finland. Religious Education Journal of Australia, 27(2), 3-9.

Ubani, M. (2012a). What characterizes the competent RE teacher? Finnish student teachers' perceptions at the beginning of their pedagogical training. British Journal of Religious Education, 34(1), 35-50. 
Ubani, M. (2012b). Does it make any difference? The case of the quantitative changes in Finnish RE student teachers' views of competence during their pedagogical program. Journal of Religious Education, 60(2), 46-57.

Ubani, M. (2015). Teaching religious education as a second choice. The case of three male student teachers in Finland. Journal of Beliefs and Values, 36(2), 190-203.

Ubani, M. (2016). RE student teachers' professional development in initial teacher education: results, reflections and implications. British Journal for Religious Education, 38(2), 189-199.

Ubani, M. (2018). When teachers face religion in public education. Case examples from Finnish public education. Journal of Religious Education, 6(22), 139-150. https://doi.org/10.1007/s40839-018-0064-x

Ubani, M. (2019). Religion and multiculturalism in Finnish public schools. The secularist - culturalist transition. In M. Ubani, I. Rissanen, \& S. Poulter (Eds.), Contextualising dialogue, pluralism and secularisation. Cases analyses on Finnish public education. Münster: Waxmann. In press.

Ubani, M., Rissanen, I., \& Poulter, S. (2019). Contextualising dialogue, secularisation and pluralism. Religion in Finnish public education. Münster: Waxmann. In press.

Ubani, M., \& Tirri, K. (2014). Religious education in Finnish schools. In M. Rothgangel, M. Jäggle, \& G. Skeie (Eds.), Religious education in schools in Europe. Part 3: Northern Europe (pp. 99-120). Wien: Vienna University Press.

UNESCO. (2012). Institute for Lifelong Learning. UNESCO guidelines for the recognition, validation and accreditation of the outcomes of Non-formal and informal learning. Hamburg: UIL.

UNESCO. (2016). A Teacher's Guide on the Prevention of Violent Extremism. France: Paris.

Viinikka, K., \& Ubani, M. (2019). The expectations of Finnish RE student teachers of their professional development in their academic studies in the light of $21^{\text {st }}$ century skills. Journal of Beliefs \& Values CJBV. doi: 10.1080/13617672.2019.1618153

Virtanen, A., \& Tynjälä, P. (2018). Factors explaining the learning of generic skills: a study of university students' experiences. Teaching in Higher Education, 2018, 115. https://doi.org/10.1080/13562517.2018.1515195

Wang, Y., Lavonen, J., \& Tirri, K. (2018). Aims for Learning 21 ${ }^{\text {st }}$ Century Competencies in National Primary Science Curricula in China and Finland. EURASIA Journal of Mathematics, Science and Technology Education, 14(6), 2081-2095.

Ziebertz, H.-G., \& Riegel, U. (Eds.). (2009) How teachers in Europe teach religion. An international empirical study in 16 countries. International Practical Theology vol 12. (pp. 57-68). LIT: Berlin. 